\title{
Synthesis of legioliulin, a fluorescent isocoumarin compound, isolated from Legionella dumoffii using cyclic acylpalladation and Heck reaction
}

\author{
Masaki Asai, ${ }^{\text {a }}$ Yasunao Hattori, ${ }^{\mathrm{b}}$ Hidefumi Makabe*a \\ ${ }^{\mathrm{a}}$ Graduate School of Science and Technology, Department of Agriculture, Division of Food Science and \\ Biotechnology, Shinshu University, 8304 Minami-minowa, Kami-ina, Nagano, 399-4598, Japan \\ ${ }^{\mathrm{b}}$ Center for Instrumental Analysis, Kyoto Pharmaceutical University, Yamashina-ku, Kyoto 607-8412, Japan \\ *Corresponding author. Tel. +81 26577 1630; fax +81 26577 1700; e-mail: makabeh@shinshu-u.ac.jp
}

\begin{abstract}
Concise synthesis of legioliulin, an isocoumarin compound isolated from Legionella dumoffii, was achieved. Isocoumarin ring of legioliulin was constructed using cyclic acylpalladation. Chain elongation was performed using Heck reaction using $t$-butylphosphine as a ligand.
\end{abstract}

Key words: natural product, polyketides, isocoumarin, acylpalladation, Heck reaction

Legionellae, which are responsible for Legionnaire's disease, are facultative intracellular gram-negative bacteria. $^{1} 10$ species of Legionella exhibit blue-white and dark-red autofluorescence. In 2004, AmemuraMaekawa and co-workers isolated legioliulin (1) from Legionella dumoffii. ${ }^{2}$ Legioliulin (1) is a new isocoumarin compound and fluorescent substance. The study on biosynthesis of legioliulin (1) was reported by Bode and coworkers in 2013. ${ }^{3}$ This compound did not show any cytotoxicity against human monocytic cell line U937, neither exhibit antimicrobial activity against Staphylococcus aureus and E. coli. ${ }^{2}$ The real function and the detailed biological activity of legioliulin (1) are still unknown. Thus we began to synthesize legioliulin (1) to find out its function and biological properties. Here, we wish to report the consice synthesis of legioliulin (1) using cyclic acylpalladation and Heck reaction as the key steps (Figure 1).

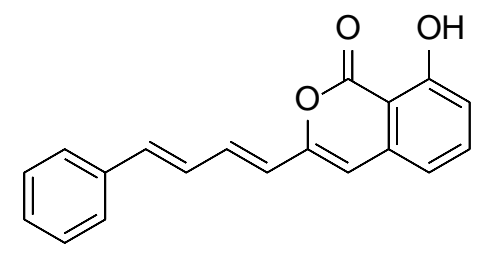

legioliulin (1)

Figure 1. The structure of legioliulin (1).

The synthetic strategy shows in Scheme 1. The side chain would be introduced using Heck reaction. The isocoumarin part of $\mathbf{1}$ would be constructed using cyclic acyl palladation trapping by $O$-enolate from iodoenone 4 . Iodoenone 4 would be prepared from known aldehyde $5 .{ }^{4}$ Aldehyde 5 would be synthesized from commercially available 3-methoxyphenylacetic acid (Scheme 1). 


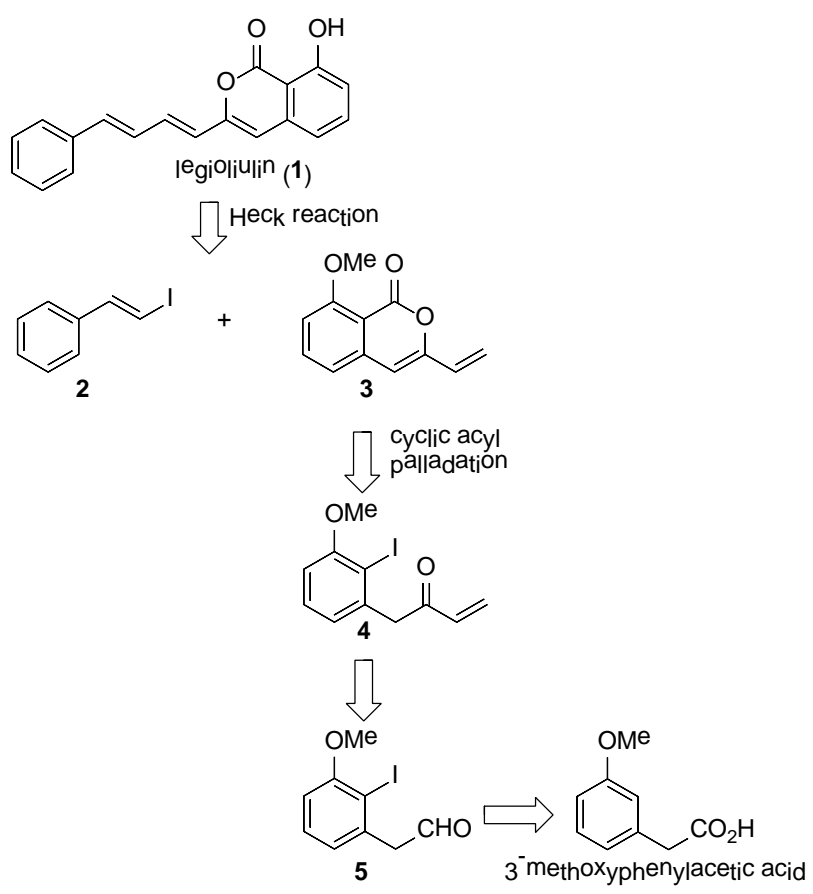

Scheme 1. Synthetic strategy of boronolide (1) and deacetylboronolide (2).

Scheme 2 shows the preparation of cyclization precursor 4. Reduction of carboxylic acid of 3methoxyphenylacetic acid with $\mathrm{LiAlH}_{4}$ afforded corresponding alcohol subsequent iodination at ortho position and oxidation of primary alcohol gave aldehyde 5. The yield of iodination was rather low because this compound was unstable. Alkylation of 5 using vinylmagnesium bromide afforded allylic alcohol 6. Oxidation of the secondary hydroxy group of $\mathbf{6}$ with Dess-Martin periodinane in the presence of pyridine gave enone 4 (Scheme 2).

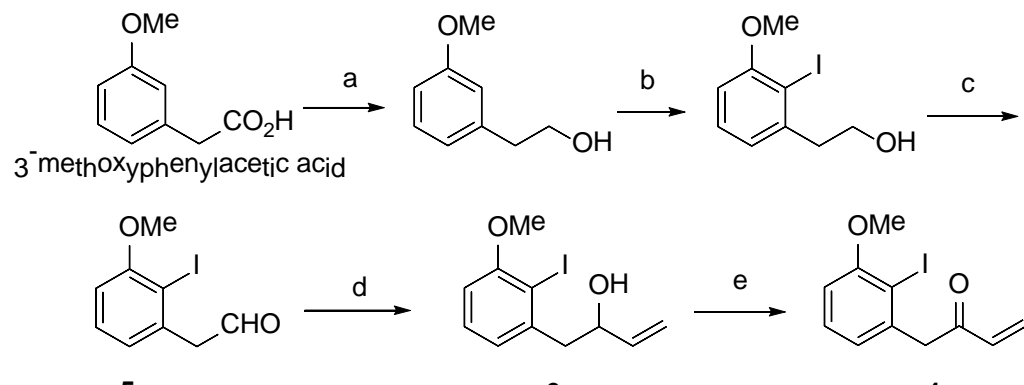

5

6

4

Scheme 2. Synthesis of cyclization precursor 4. Reagents and conditions: (a) $\mathrm{LiAlH}_{4}, \mathrm{THF}, 96 \%$; (b) $n$-BuLi, $\mathrm{I}_{2}$, $\mathrm{Et}_{2} \mathrm{O}$, 48\%; (c) Dess-Martin periodinane, $\mathrm{CH}_{2} \mathrm{Cl}_{2}, 99 \%$; (d) vinylmagnesium bromide, $\mathrm{Et}_{2} \mathrm{O}$, 89\%; (e) DessMartin periodinane, pyridine, $\mathrm{CH}_{2} \mathrm{Cl}_{2}, 74 \%$.

The cyclization precursor was in hand, we examined cyclic acylpalladation trapping by $O$-enolate to obtain 3 . $^{5-9}$ As shown in Table 1, the choice of the base and solvent was very important. We found that AcONa as a base in $\mathrm{DMF}$ at $50^{\circ} \mathrm{C}$ furnished desired 5-O-endo cyclized product 3 in 57\% yield. Raising reaction temperature and changing solvent did not improve the yield. We also examined other Pd catalyst such as $\mathrm{Pd}\left(\mathrm{PPh}_{3}\right)_{4}$ and $\mathrm{Pd}(\mathrm{dba})_{2}$ with ligand such as dppf and dppp. However, the yield of $\mathbf{3}$ was not improved (Table 1). 


\section{Table 1. Cyclic acylpalladation of 4.}

\begin{tabular}{|c|c|c|c|}
\hline base & solvent & temperature $\left({ }^{\circ} \mathrm{C}\right)$ & yield $(\%)$ \\
\hline $\mathrm{Et}_{3} \mathrm{~N}^{\prime} \mathrm{K}_{2} \mathrm{CO}_{3}{ }^{\mathrm{a}^{\prime} 10}$ & THF & 40 & 35 \\
\hline $\mathrm{K}_{2} \mathrm{CO}_{3}{ }^{\prime} \mathrm{NH}_{2} \mathrm{NH}_{2}{ }^{11}$ & THF & 40 & 10 \\
\hline $\mathrm{Et}_{3} \mathrm{~N}$ & DMF & 50 & 33 \\
\hline $\mathrm{K}_{2} \mathrm{CO}_{3}$ & DMF & 50 & 16 \\
\hline $\mathrm{NaHCO}_{3}$ & DMF & 50 & 23 \\
\hline $\mathrm{CS}_{2} \mathrm{CO}_{3}$ & DMF & 50 & 11 \\
\hline ACONa & DMF & 50 & 57 \\
\hline ACONa & DMF & 70 & 32 \\
\hline ACONa & DMF & 100 & 10 \\
\hline ACONa & toluene & 50 & 14 \\
\hline ACONa & dioxane & 50 & 16 \\
\hline ACONa & DMF & 50 & $33^{b}$ \\
\hline
\end{tabular}

Next, we investigated the construction of the carbon framework of legioliulin (1) using Heck reaction. In this reaction, we found that the phosphine ligand greatly affected the reactivity. We previously reported that $\mathrm{P}(t-\mathrm{Bu})_{3}$ was effective ligand to form stilbene framework. ${ }^{12} \mathrm{Fu}$ reported that the effect of $\mathrm{P}(t-\mathrm{Bu})_{3} \cdot{ }^{13}$ According to his report, the effect of $\mathrm{P}(t-\mathrm{Bu})_{3}$ is electron donating as well as accelerating reductive elimination. As a result $\mathrm{P}(t-$ $\mathrm{Bu})_{3}$ afforded desired product 7 in 66\% yield (Table 2).

\section{Table 2. Heck reaction of 3 with (1E)-1-iodostyrene (2).}

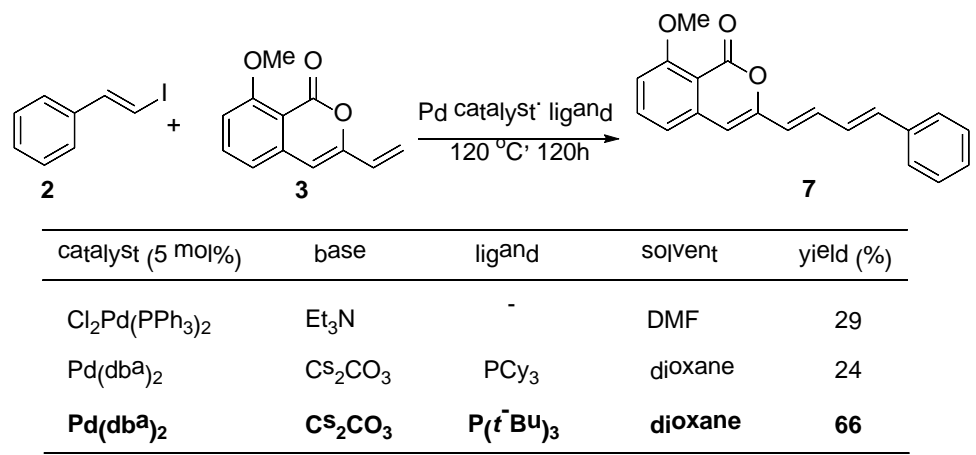

Finally, deprotection of methyl group at C-8 position using $\mathrm{BBr}_{3}$ in $\mathrm{CH}_{2} \mathrm{Cl}_{2}$ at $-78^{\circ} \mathrm{C}$ gave legioliulin (1). The ${ }^{1} \mathrm{H}$ and ${ }^{13} \mathrm{C}$ NMR data of the synthetic legioliulin (1) were consistent with those of the reported values (Scheme 3). ${ }^{2,14}$ 


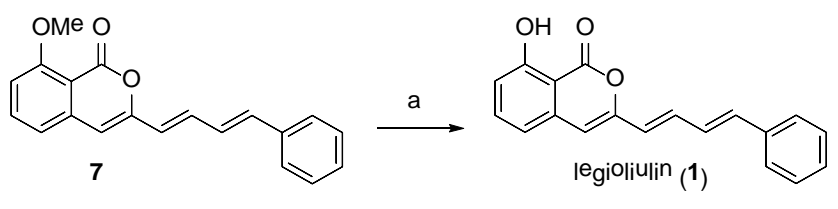

Scheme 3. Synthesis of legioliulin (1). Reagent and condition: (a) $\mathrm{BBr}_{3}, \mathrm{CH}_{2} \mathrm{Cl}_{2},-78^{\circ} \mathrm{C}, 76 \%$.

In conclusion, concise synthesis of legioliulin (1) was achieved using acylpalladation and Heck reaction. The studies on biological activities of legioliulin (1) is now underway.

\section{Acknowledgements}

This work was supported by JSPS KAKENHI Grant Number 15K07408 to H. M.

\section{References and notes}

1. Fields, B. S.; Benson, R. F.; Besser, R. E. Clin. Microbiol. Rev. 2002, 15, 506.

2. Amemura-Maekawa, J.; Hayakawa, Y.; Sugie, H.; Moribayashi, A.; Kura, F.; Chang, B.; Wada, A.; Watanabe, H. Biochem. Biophys. Res. Commun. 2004, 323, 954.

3. Ahrendt, T.; Miltenberger, M.; Haneburger, I.; Kirchner, F.; Kronewerth, M.; Brachmann, A. O.; Hilbi, H,; Bode, H. B. ChemBioChem. 2013, 14, 1415.

4. Fan, L.; Takizawa, S.; Takeuchi, Y.; Takenaka, K.; Sasai, H. Org. Biomol. Chem. 2015, 13, 4837.

5. Negishi, E.; Makabe, H. Handbook of Organopalladium Chemistry for Organic Synthesis, John Wiley \& Sons: New York, 2002, 2455.

6. Negishi, E.; Copéret, C.; Ma, S.; Liou, S. Y.; Liu, F. Chem. Rev. 1996, 96, 365.

7. Negishi, E.; Copéret, C.; Sugihara, T.; Shimoyama, I.; Zhang, Y.; Wu, G.; Tour, J. M. Tetrahedron 1994, 50, 425.

8. Negishi, E.; Makabe, H.; Shimoyama, I.; Wu, G.; Zhang, Y.; Tetrahedron 1998, 54, 1095

9. Uozumi, Y.; Mori, E.; Mori, M.; Shibasaki, M. J. Organomet. Chem. 1990, 399, 93.

10. Makabe, H.; Okajima, M.; Konno, H.; Kamo, T.; Hirota, M. Biosci. Biotechnol. Biochem. 2003, 67, 2658.

11. Hikosaka, G.; Hattori, Y.; Makabe, H. Tetrahedron: Asymmetry 2014, 25, 1367.

12. Iijima, T.; Makabe, H. Biosci. Biotechol. Biochem. 2009, 73, 2547.

13. Fu, G. C. Acc. Chem. Res. 2008, 41, 1555. 
14. The data of legioliulin (1): Mp. 107-108º C IR (KBr): 3250-3025, 2917, 2849, 1687, 1625, 1609, 1562, 1496, 1460, 1343, 1315, 1223, 1168, 1141, 1090, 1049, 982, 842, 749, $690 \mathrm{~cm}^{-1}$; ${ }^{1} \mathrm{H}$ NMR (500 MHz, $\left.\mathrm{CDCl}_{3}\right) \delta: 11.00(1 \mathrm{H}, \mathrm{s}), 7.55(1 \mathrm{H}, \mathrm{t}, J=7.5 \mathrm{~Hz}), 7.45(2 \mathrm{H}, \mathrm{d}, J=7.5 \mathrm{~Hz}), 7.34(2 \mathrm{H}, \mathrm{t}, J=7.5 \mathrm{~Hz})$, $7.26(1 \mathrm{H}, \mathrm{t}, J=7.5 \mathrm{~Hz}), 7.22(1 \mathrm{H}$, dd, $J=15.0,11.0 \mathrm{~Hz}), 6.92(1 \mathrm{H}, \mathrm{d}, J=7.5 \mathrm{~Hz}), 6.89(1 \mathrm{H}, \mathrm{dd}, J=$ 15.5, $11.0 \mathrm{~Hz}), 6.86(1 \mathrm{H}, \mathrm{d}, J=7.5 \mathrm{~Hz}), 6.81$ (1H, d, $J=15.5 \mathrm{~Hz}), 6.39(1 \mathrm{H}, \mathrm{s}), 6.24$ (1H, d, $J=15.0$ $\mathrm{Hz}) ;{ }^{13} \mathrm{C}$ NMR (125 MHz, $\mathrm{CDCl}_{3}$ ) $\delta:$ 166.00, 161.71, 152.06, 137.94, 137.32, 137.03, 136.63, 133.81, 128.80, 128.42, 127.45, 126.83, 122.36, 116.31, 115.24, 106.39, 106.05 ppm. HRMS-EI: m/z [M] $]^{+}$ calcd for $\mathrm{C}_{19} \mathrm{H}_{14} \mathrm{O}_{3}$; 290.0943, found: 290.0945. 